\title{
In vitro Antimicrobial Activity of Linezolid Tested Against Vancomycin-Resistant Enterococci Isolated in Brazilian Hospitals
}

\author{
Adriana O. Reis, Julio C. R. Cordeiro \\ Antonia M.O. Machado and Helio S. Sader
}

\author{
Special Clinical Microbiology Laboratory, Division \\ of Infectious Diseases, Federal University of São Paulo, \\ SP, Brazil; Microbiology Laboratory of São Paulo \\ Hospital, Federal University of São Paulo, Brazil
}

\begin{abstract}
The emergence of vancomycin-resistant enterococci (VRE) has been described recently in Brazil. This is in contrast to the USA and Europe, where the VRE appeared in the late 1980s. The progressive increase in VRE isolation poses important problems in the antimicrobial therapy of nosocomial infections. Treatment options and effective antimicrobial agents for VRE are often limited and the possibility of transfer of vancomycin genes to other Gram-positive microorganisms continues. In the search for antimicrobial agents for multiresistant Gram-positive cocci, compounds such as linezolid and quinupristin/dalfopristin have been evaluated. The present study was conducted to evaluate the in vitro activity of the oxazolidinone linezolid and 10 other antimicrobial agents, including quinupristin-dalfopristin, against multiresistant enterococci isolated in Brazilian hospitals. Thirty-three vancomycin resistant isolates (17 Enterococcus faecium and 16 E. faecalis), were analyzed. Strains were isolated from patients at São Paulo Hospital, Oswaldo Cruz Hospital, Hospital do Servidor Público Estadual, Santa Marcelina Hospital, Santa Casa de Misericórdia de São Paulo, and Hospital de Clínicas do Paraná. The samples were tested by a broth microdilution method following the National Committee for Clinical Laboratory Standards (NCCLS) recommendations. All isolates were molecular typed using pulsed-field gel electrophoresis (PFGE). Linezolid was the most active compound against these multiresistant enterococci, showing $100 \%$ inhibition at the susceptible breakpoints. Quinupristin/dalfopristin and teicoplanin showed poor activity against both species. The molecular typing results suggest that there has been interhospital spread of vancomycin resistant $E$. faecium and $E$. faecalis among Brazilian hospitals. The results of this study indicate that linezolid is an appropriate therapeutic option for the treatment of vancomycin-resistant enterococci infections in Brazil.

Key words: Linezolid, vancomycin-resistant enterococci, quinupristin/dalfopristin-resistant Enterococcus faecium, clonal dissemination, nosocomial infection.
\end{abstract}

Enterococci are considered opportunistic pathogens that frequently cause infections in patients hospitalized for a long period of time and/or receiving multiple courses

Received on 8 February 2001; revised 26 June 2001.

Address for correspondence: Dr. Hélio S. Sader. Laboratório Especial de Microbiologia Clínica, Disciplina de Doenças Infecciosas e Parasitárias, Universidade Federal de São Paulo - EPM. Rua Botucatu, 740. São Paulo, SP. Zip Code: 04023063 - Brazil. Phone: (55 11) 5081-2819/ 5571-5180/ 5576-4393. Fax:(55 11) 5543-3013/5571-5180.

The Brazilian Journal of Infectious Diseases 2001;5(5):243-251 (C) 2001 by The Brazilian Journal of Infectious Diseases and Contexto Publishing. All rights reserved.

$1413-8670$ of antimicrobial therapy [1]. According to the Centers for Disease Control and Prevention, the percentage of nosocomial enterococal infections caused by strains resistant to vancomycin increased from $0.3 \%$ in 1989 , to $15 \%$ in 1996 [2]. E. faecalis and E. faecium are the 2 most common species routinely isolated by clinical microbiology laboratories [3]. Both species are intrinsically resistant to cephalosporins. Ampicillin resistance among $E$. faecalis isolates is generally rare [3]. In contrast, E. faecium strains usually show high rates of resistance to most antimicrobial agents [3]. Vancomycin resistance has been observed predominantly in E. faecium and can be as high as $47 \%$ in the USA [4]. 
Acquired resistance to glycopeptides in enterococci is due to the production of peptidoglycan precursor ending in the depsipeptide D-alanyl-Dlactate (D-Ala-D-Lac) instead of the dipeptide DAla-D-ala produced by susceptible bacteria [5]. This substitution prevents the formation of the complexes between glycopeptides and peptidoglycan precursors at the cell surface, leading to inhibition of cell wall synthesis [5]. The genes encoding this mechanism of resistance are $\operatorname{van} \mathrm{A}, \operatorname{van} \mathrm{B}, \operatorname{van} \mathrm{D}$, and $\operatorname{van} \mathrm{E}[5,6]$. Species such as E. gallinarum, E. casseliflavus and E. flavescens show low level resistance to vancomycin due to the presence of chromosomally encoded vanC genes [5,6].

In contrast to the USA and Europe, where VRE emerged in the 1980s, the emergence of VRE was only recently described in Brazil. The first isolation of a Brazilian VRE strain occurred in 1997, in Southern Brazil [7]. More recently, several cases of VRE were described in the Santa Marcelina Hospital in São Paulo city. Most cases were described as colonization by the pathogen, rather than clinical infection. Several isolates had identical or similar PFGE patterns, suggesting clonal dissemination [8]. In addition, VRE isolates showing the same PFGE were detected in several other hospitals located in São Paulo [8]. These findings indicate that this pathogen can easily disseminate within a hospital or even among different hospitals [5].

The emergence and dissemination of VRE is of great concern since treatment options for VRE infections are often limited. In the search for therapeutic agents for serious Gram-positive infections, compounds such as linezolid and quinupristin/dalfopristin have been recently approved for clinical use in several countries for serious and life threatening infections caused by strains of vancomycin-resistant $E$. faecium and for complicated skin and soft tissue infections [9,10]. In the United Kingdom, quinupristin/dalfopristin is licensed specifically for skin and soft tissue infections, nosocomial pneumonia and for E. faecium infections "where no other drug is appropriate" [11]. In addition, resistance to quinupristin/dalfopristin among E. faecium has been observed in Latin America, especially in São Paulo [8].
Linezolid (formally U-100766) is an oxazolidinone, an antimicrobial class unrelated to other known antimicrobial agents [11-13]. This compound inhibits the formation of the initiation complex constructed with 30S ribosomes, mRNA, initiation factors IF2 and IF3, and $\mathrm{fMet}-\mathrm{RNA}[4,13,14]$. In vitro and in vivo studies have demonstrated that linezolid has significant antimicrobial activity against multiresistant Grampositive pathogens including VRE, methicillin-resistant strains of Staphylococcus aureus and Staphylococcus epidermidis, penicillin-resistant pneumococci, Corynebacterium spp. and Listeria monocytogenes. Anaerobes such as Clostridium spp., Peptostreptococcus spp. and Prevotella spp. are also susceptible to linezolid [15].

Linezolid is bacteriostatic against most susceptible organisms, but displays bactericidal activity against some strains of pneumococci, Bacteroides fragilis, and $C$. perfringens [15]. In addition, due to its unique mechanism of action, cross-resistance with other classes of antimicrobial agents is not described, and bacterial rate of spontaneous mutation to resistance is very low. This may translate to a low incidence of resistance during therapy $[4,15]$.

This study was conducted to evaluate the in vitro activity of the oxazolidinone linezolid against vancomycin-resistant enterococci isolated in Brazilian hospitals.

\section{Materials and Methods}

$\underline{\text { Bacterial strains }}$

Thirty-three vancomycin resistant isolates were analyzed, 17 Enterococcus faecium and $16 \mathrm{E}$. faecalis. These strains were isolated from patients hospitalized at the following hospitals: São Paulo Hospital - Federal University of São Paulo, São Paulo (8 E. faecalis); Oswaldo Cruz Hospital, São Paulo (4 E. faecalis); Hospital do Servidor Público Estadual, São Paulo (2 E. faecalis and 6 E. faecium); Santa Marcelina Hospital, São Paulo (8 E. faecium and 1 E. faecalis ); Santa Casa de 
Table 1. Antimicrobial activities of linezolid and reference compounds against clinical isolates of vancomycin resistant enterococci

\begin{tabular}{|c|c|c|c|c|c|}
\hline \multicolumn{6}{|c|}{$\operatorname{MIC}(\mu \mathrm{g} / \mathrm{mL})$} \\
\hline Organism (no $)$ & $\begin{array}{l}\text { Antimicrobial } \\
\text { Agents }\end{array}$ & $\mathrm{MIC}_{50}$ & $\mathrm{MIC}_{90}$ & Range & \% Susceptible \\
\hline Enterococcus & Linezolid & 2.0 & 2.0 & $1-2$ & 100.0 \\
\hline \multirow[t]{10}{*}{ faecalis (16) } & $\begin{array}{l}\text { Quinupristin/ } \\
\text { Dalfopristin }\end{array}$ & $>8$ & $>8$ & $4->8$ & 0.0 \\
\hline & Teicoplanin & $>16$ & $>16$ & $>16$ & 0.0 \\
\hline & Vancomycin & $>16$ & $>16$ & $>16$ & 0.0 \\
\hline & Ampicillin & 1.5 & 4.0 & $0.5-8$ & 100.0 \\
\hline & Gentamicin & $>1000$ & $>1000$ & $>1000$ & 0.0 \\
\hline & Streptomycin & $\leq 1000$ & $\leq 1000$ & $\leq 1000$ & 100.0 \\
\hline & Doxycycline & 2.0 & 4.0 & $\leq 0.5-4$ & 100.0 \\
\hline & Erythromycin & $>8$ & $>8$ & $>8$ & 0.0 \\
\hline & Chloramphenicol & $>16$ & $>16$ & $8->16$ & 18.8 \\
\hline & Rifampin & 2.0 & $>2.0$ & $2->2$ & 0.0 \\
\hline Enterococcus & Linezolid & 2.0 & 2.0 & $1-2$ & 100.0 \\
\hline \multirow[t]{10}{*}{ faecium (17) } & $\begin{array}{l}\text { Quinupristin/ } \\
\text { Dalfopristin }\end{array}$ & 4.0 & $>8.0$ & $1->8$ & 11.8 \\
\hline & Teicoplanin & $>16$ & $>16$ & $>16$ & 0.0 \\
\hline & Vancomycin & $>16$ & $>16$ & $>16$ & 0.0 \\
\hline & Ampicillin & $>16$ & $>16$ & $>16$ & 0.0 \\
\hline & Gentamicin & $>1000$ & $>1000$ & $>1000$ & 0.0 \\
\hline & Streptomycin & $\leq 1000$ & $\leq 1000$ & $\leq 1000$ & 100.0 \\
\hline & Doxycycline & $\leq 0.5$ & 2.0 & $\leq 0.5->4$ & 94.1 \\
\hline & Erythromycin & $>8$ & $>8$ & $>8$ & 0.0 \\
\hline & Chloramphenicol & 8.0 & $>16$ & $2->16$ & 64.7 \\
\hline & Rifampin & $>2$ & $>2$ & $2->8$ & 0.0 \\
\hline
\end{tabular}

Misericórdia de São Paulo, São Paulo (2 E. faecium and 1 E. faecalis ); Hospital de Clínicas do ParanáFederal University of Paraná, Curitiba (1 E. faecium). Only 1 isolate per patient was included in the study. The isolates were identified to the species level using the conventional biochemical tests described by Facklam, et al. [16].

\section{$\underline{\text { Susceptibility tests }}$}

The samples were tested by broth microdilution method following the National Committee for Clinical Laboratory Standards (NCCLS) recommendations [17]. The minimum inhibitory concentration (MIC) was determined for linezolid, quinupristin-dalfopristin, 
Table 2. Antimicrobial susceptibility of clinical isolates of vancomycin resistant enterococci

\begin{tabular}{|c|c|c|c|c|c|c|c|c|}
\hline \multirow{2}{*}{$\begin{array}{l}\text { Hospitals }^{a} \\
\text { Organism }\left(n^{0}\right)\end{array}$} & \multicolumn{7}{|c|}{ Minimum inhibitory concentration in $\mu \mathrm{g} / \mathrm{mL}$ (category) ${ }^{b}$} & \multirow[t]{2}{*}{ PFGE $^{c}$} \\
\hline & & Linezolid d $^{d}$ & $Q / D^{d}$ & Ampi $^{d}$ & $\operatorname{Doxy}^{d}$ & Chlo $^{d}$ & Rif $^{d}$ & \\
\hline E. faecalis & HSP & $2(\mathrm{~S})$ & $>8(\mathrm{R})$ & $0.5(\mathrm{~S})$ & $2(\mathrm{~S})$ & $8(\mathrm{~S})$ & $2(\mathrm{I})$ & I \\
\hline \multirow[t]{15}{*}{ (16) } & HSP & $1(\mathrm{~S})$ & $>8(\mathrm{R})$ & $1(\mathrm{~S})$ & $2(\mathrm{~S})$ & $>16(\mathrm{R})$ & $>2(\mathrm{R})$ & I \\
\hline & HSP & $1(\mathrm{~S})$ & $8(\mathrm{R})$ & $2(\mathrm{~S})$ & $2(\mathrm{~S})$ & $>16(\mathrm{R})$ & 2 (I) & I \\
\hline & HSP & $2(\mathrm{~S})$ & $>8(\mathrm{R})$ & $1(\mathrm{~S})$ & $2(\mathrm{~S})$ & $>16(\mathrm{R})$ & 2 (I) & I \\
\hline & HSP & $2(\mathrm{~S})$ & $>8(\mathrm{R})$ & $1.5(\mathrm{~S})$ & $4(\mathrm{~S})$ & $>16(\mathrm{R})$ & $>2(\mathrm{R})$ & I \\
\hline & $\mathrm{HOC}$ & $2(\mathrm{~S})$ & $4(\mathrm{R})$ & $1.5(\mathrm{~S})$ & $\leq 0.5(\mathrm{~S})$ & $8(\mathrm{~S})$ & $>2(\mathrm{R})$ & II \\
\hline & $\mathrm{HOC}$ & $1(\mathrm{~S})$ & $>8(\mathrm{R})$ & $1.5(\mathrm{~S})$ & $2(\mathrm{~S})$ & $>16(\mathrm{R})$ & 2 (I) & II \\
\hline & $\mathrm{HOC}$ & $1(\mathrm{~S})$ & $>8(\mathrm{R})$ & $1.5(\mathrm{~S})$ & $4(\mathrm{~S})$ & $>16(\mathrm{R})$ & $>2(\mathrm{R})$ & II \\
\hline & $\mathrm{HOC}$ & $2(\mathrm{~S})$ & $>8(\mathrm{R})$ & $0.5(\mathrm{~S})$ & $4(\mathrm{~S})$ & $>16(\mathrm{R})$ & $>2(\mathrm{R})$ & II \\
\hline & SM & $2(\mathrm{~S})$ & $>8(\mathrm{R})$ & $3(\mathrm{~S})$ & $2(\mathrm{~S})$ & $>16(\mathrm{R})$ & $2(\mathrm{I})$ & II \\
\hline & HSP & $2(\mathrm{~S})$ & $>8(\mathrm{R})$ & $6(S)$ & $2(\mathrm{~S})$ & $>16(\mathrm{R})$ & $>2(\mathrm{R})$ & I \\
\hline & HSP & $1(\mathrm{~S})$ & $8(\mathrm{R})$ & $8(\mathrm{~S})$ & $1(\mathrm{~S})$ & $8(\mathrm{~S})$ & 2 (I) & I \\
\hline & HSP & $2(\mathrm{~S})$ & $>8(\mathrm{R})$ & $1.5(\mathrm{~S})$ & $4(\mathrm{~S})$ & $>16(\mathrm{R})$ & $>2(\mathrm{R})$ & II \\
\hline & HSPE & $2(\mathrm{~S})$ & $8(\mathrm{R})$ & $1(\mathrm{~S})$ & $2(\mathrm{~S})$ & $>16(\mathrm{R})$ & $2(\mathrm{I})$ & I \\
\hline & HSPE & $2(\mathrm{~S})$ & $>8(\mathrm{R})$ & $1(\mathrm{~S})$ & $4(\mathrm{~S})$ & $>16(\mathrm{R})$ & $>2(\mathrm{R})$ & I \\
\hline & SC-SP & $1(\mathrm{~S})$ & $>8(\mathrm{R})$ & $4(S)$ & $1(\mathrm{~S})$ & $>16(\mathrm{R})$ & $2(\mathrm{I})$ & I \\
\hline \multirow{17}{*}{$\begin{array}{l}\text { E. faecium } \\
\text { (17) }\end{array}$} & HSPE & $1(\mathrm{~S})$ & $4(\mathrm{R})$ & $>16(\mathrm{R})$ & $\leq 0.5(\mathrm{~S})$ & $4(\mathrm{~S})$ & $>2(\mathrm{R})$ & $\mathrm{E}$ \\
\hline & $\mathrm{SM}$ & $2(\mathrm{~S})$ & $4(\mathrm{R})$ & $>16(\mathrm{R})$ & $\leq 0.5(\mathrm{~S})$ & $8(\mathrm{~S})$ & $>2(\mathrm{R})$ & $\mathrm{A} 2$ \\
\hline & SC-SP & $2(\mathrm{~S})$ & $4(\mathrm{R})$ & $>16(\mathrm{R})$ & $\leq 0.5(\mathrm{~S})$ & $8(\mathrm{~S})$ & $>2(\mathrm{R})$ & A1 \\
\hline & SM & $2(\mathrm{~S})$ & $4(\mathrm{R})$ & $>16(\mathrm{R})$ & $\leq 0.5(\mathrm{~S})$ & $8(\mathrm{~S})$ & $>2(\mathrm{R})$ & A1 \\
\hline & SM & $2(\mathrm{~S})$ & $4(\mathrm{R})$ & $>16(\mathrm{R})$ & $\leq 0.5(\mathrm{~S})$ & $8(S)$ & $>2(\mathrm{R})$ & A3 \\
\hline & SM & $2(\mathrm{~S})$ & $4(\mathrm{R})$ & $>16(\mathrm{R})$ & $\leq 0.5(\mathrm{~S})$ & $8(\mathrm{~S})$ & $>2(\mathrm{R})$ & A4 \\
\hline & HC-UFPR & $2(\mathrm{~S})$ & $1(\mathrm{~S})$ & $>16(\mathrm{R})$ & $4(\mathrm{~S})$ & $>16(\mathrm{R})$ & $>2(\mathrm{R})$ & $\mathrm{D}$ \\
\hline & $\mathrm{SM}$ & $1(\mathrm{~S})$ & $1(\mathrm{~S})$ & $>16(\mathrm{R})$ & $2(\mathrm{~S})$ & $>16(\mathrm{R})$ & $>2(\mathrm{R})$ & $\mathrm{H}$ \\
\hline & HSPE & $2(\mathrm{~S})$ & $4(\mathrm{R})$ & $>16(\mathrm{R})$ & $1(\mathrm{~S})$ & $>16(\mathrm{R})$ & 2 (I) & A1 \\
\hline & HSPE & $2(\mathrm{~S})$ & $4(\mathrm{R})$ & $>16(\mathrm{R})$ & $\leq 0,5(\mathrm{~S})$ & $>16(\mathrm{R})$ & $>2(\mathrm{R})$ & $\mathrm{A} 2$ \\
\hline & HSPE & $2(\mathrm{~S})$ & $4(\mathrm{R})$ & $>16(\mathrm{R})$ & $\leq 0.5(\mathrm{~S})$ & $2(\mathrm{~S})$ & $>2(\mathrm{R})$ & A1 \\
\hline & SC-SP & $2(\mathrm{~S})$ & $4(\mathrm{R})$ & $>16(\mathrm{R})$ & $\leq 0.5(\mathrm{~S})$ & $8(\mathrm{~S})$ & $>2(\mathrm{R})$ & A1 \\
\hline & HSPE & $2(\mathrm{~S})$ & $4(\mathrm{R})$ & $>16(\mathrm{R})$ & $2(\mathrm{~S})$ & $4(\mathrm{~S})$ & $>2(\mathrm{R})$ & A1 \\
\hline & $\mathrm{SM}$ & $2(\mathrm{~S})$ & $4(\mathrm{R})$ & $>16(\mathrm{R})$ & $\leq 0.5(\mathrm{~S})$ & $8(\mathrm{~S})$ & $>2(\mathrm{R})$ & A1 \\
\hline & $\mathrm{SM}$ & $2(\mathrm{~S})$ & $4(\mathrm{R})$ & $>16(\mathrm{R})$ & $\leq 0.5(\mathrm{~S})$ & $8(\mathrm{~S})$ & $>2(\mathrm{R})$ & $\mathrm{G}$ \\
\hline & $\mathrm{SM}$ & $2(\mathrm{~S})$ & $>8(\mathrm{R})$ & $>16(\mathrm{R})$ & $1(\mathrm{~S})$ & $>16(\mathrm{R})$ & $>2(\mathrm{R})$ & $\mathrm{L}$ \\
\hline & HSPE & $1(\mathrm{~S})$ & $>8(\mathrm{R})$ & $>16(\mathrm{R})$ & $2(\mathrm{~S})$ & $>16(\mathrm{R})$ & $>2(\mathrm{R})$ & A1 \\
\hline
\end{tabular}

${ }^{a}$ HSP = São Paulo Hospital; HOC = Oswaldo Cruz Hospital; HSPE = Hospital do Servidor Público Estadual; SM= Santa Marcelina Hospital; SC-SP = Santa Casa de São Paulo; HC-PR - Hospital de Clínicas do Paraná; b S: susceptible; I: intermediate; R: resistant. All isolates showed resistance to vancomycin (MIC, $\geq 256 \mu \mathrm{g} / \mathrm{mL}$ ), teicoplanin (MIC, $\geq 256 \mathrm{mg} / \mathrm{mL}$ ) erythromycin (MIC, $\geq 16 \mathrm{mg} / \mathrm{mL}$ ) and high level resistance to gentamicin $(\mathrm{MIC},>500 \mathrm{mg} / \mathrm{mL}) ;{ }^{\mathrm{c}}$ Antimicrobial Agents: Q/D = quinupristin/dalfopristin; Ampi = ampicillin; Doxy = doxycycline; Chlo = chloramphenicol; Rif = rifampin; ${ }^{\mathrm{d}}$ Pulsed Field Gel Electrophoresis patterns. 
Figure 1. PFGE patterns of SmaI digested chromossomal DNA showing examples of vancomycin-resistant Enterococcus faecalis with PFGE patterns I (lanes 1 - 6) and II (lanes 7 - 12) from different hospitals. Patterns I and II were considered similar since they differ from each other by only two bands. $\lambda: 48.5 \mathrm{~Kb}$ lambda ladder.

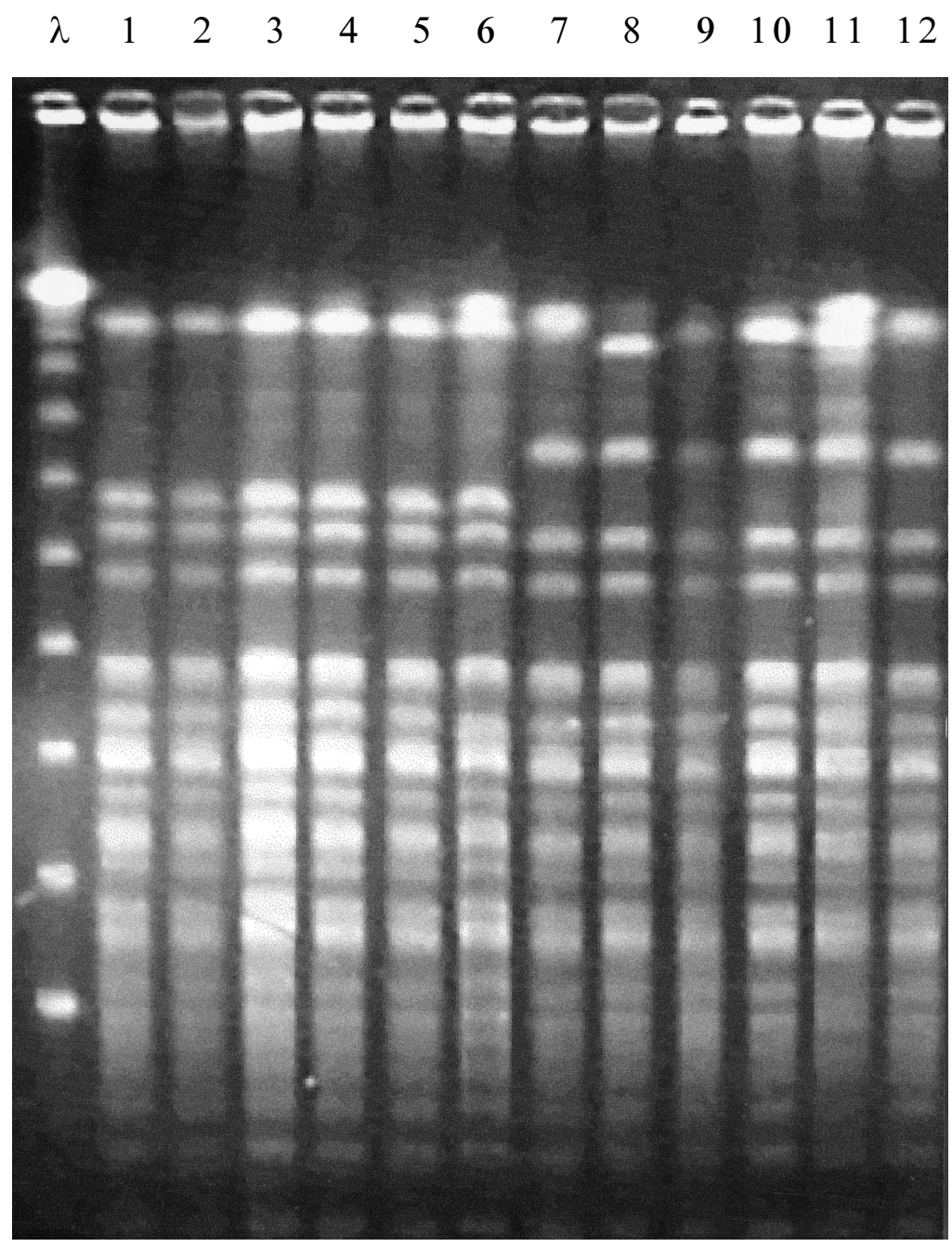


ampicillin, doxycycline, chloramphenicol, rifampin, gentamicin, streptomycin, erythromycin, vancomycin and teicoplanin [18]. Pure colonies were suspended in $5 \mathrm{ml}$ of Mueller-Hinton broth in order to match $0.5 \mathrm{Mc}$ Farland turbidity standard. Then, $50 \mu \mathrm{L}$ were transferred to $10 \mathrm{~mL}$ of Mueller Hinton and mixed well. Once the inoculum suspension was prepared, $100 \mu \mathrm{L}$ of this suspension were transferred to each plate well. The plates were incubated at $35^{\circ} \mathrm{C}$ in an ambient air incubator for $16 \mathrm{~h}$ to $20 \mathrm{~h}$. The vancomycin results were interpreted after $24 \mathrm{~h}$ of incubation. The samples were categorized as susceptible, intermediate or resistant, according to susceptibility ranges established for dilution methods by the NCCLS [18].

The breakpoints for susceptibility and resistance are, respectively: quinupristin/dalfopristin at $\leq 1 \mu \mathrm{g} / \mathrm{mL}$ and $\geq 4 \mu \mathrm{g} / \mathrm{mL}$; rifampin at $\leq 1 \mu \mathrm{g} / \mathrm{mL}$ and $\geq 4 \mu \mathrm{g} / \mathrm{mL}$; chloramphenicol at $\leq 8 \mu \mathrm{g} / \mathrm{mL}$ and $\geq 32 \mu \mathrm{g} / \mathrm{mL}$; doxycycline at $\leq 4 \mu \mathrm{g} / \mathrm{mL}$ and $\geq 16 \mu \mathrm{g} / \mathrm{mL}$; teicoplanin at $\leq 8 \mu \mathrm{g} / \mathrm{mL}$ and $\geq 32 \mu \mathrm{g} / \mathrm{mL}$; vancomycin at $\leq 4 \mu \mathrm{g} / \mathrm{mL}$ and $\geq 32 \mu \mathrm{g} / \mathrm{mL}$; ampicillin $\leq 8 \mu \mathrm{g} / \mathrm{mL}$ and $\geq 16 \mu \mathrm{g} / \mathrm{mL}$; erythromycin at $\leq 0.5 \mu \mathrm{g} /$ $\mathrm{mL}$ and $\geq 8 \mu \mathrm{g} / \mathrm{mL}$, gentamicin at $\leq 500 \mu \mathrm{g} / \mathrm{mL}$ and $>500 \mu \mathrm{g} / \mathrm{mL}$ (high level); streptomycin at $\leq 1000 \mu \mathrm{g} /$ $\mathrm{mL}$ and $>1000 \mu \mathrm{g} / \mathrm{mL}$ (high level). The linezolid interpreting criteria was defined as $\leq 4 \mu \mathrm{g} / \mathrm{mL}$ to susceptibility and $\geq 16 \mu \mathrm{g} / \mathrm{mL}$ to resistance [19]. The quality control strains $S$. aureus ATCC 29213 and E. faecalis ATCC 29212 were tested along with the clinical isolates in each batch of tests.

\section{Molecular typing}

The strains were molecular typed using PFGE as described by Pfaller, et al. [20]. Restriction digestion of chromosomal DNA was performed with $S m a I$ and the resultant restriction fragments were resolved in a $1 \%$ agarose gel with CHEF-DRII system (Bio-Rad Laboratories, Richmond, CA, USA). The pulsed time ramped from $5 \mathrm{~s}$ to $30 \mathrm{~s}$ over $23 \mathrm{~h}$ at $13^{\circ} \mathrm{C}$ and $6 \mathrm{~V} / \mathrm{cm}$. PFGE patterns were considered identical if they shared every band, similar if they differed from one to another by only 1 to 3 bands, and different if they differed by 4 or more bands.

\section{Results}

Table 1 shows MICs that inhibit 50\% and 90\% of the isolates tested (MIC50 and MIC90, respectively), MIC variation and the percentage of susceptible strains for each compound evaluated. Only linezolid inhibited all isolates of both species at the susceptible breakpoint $(\leq 4 \mu \mathrm{g} / \mathrm{mL})$. The highest MIC detected for this compound was $2 \mu \mathrm{g} /$ $\mathrm{mL}$. Table 2 presents the MIC results of linezolid and 10 other antimicrobial agents against all isolates evaluated.

As expected, quinupristin/dalfopristin showed poor in vitro activity against $E$. faecalis with $100 \%$ of strains showing resistance to this compound [3]. Among E. faecium, 15 of 17 isolates (88.2\%) were resistant to quinupristin/dalfopristin.

High level resistance to streptomycin was not detected among the isolates evaluated and doxycycline showed excellent in vitro activity against both species (94.1\% susceptibility among E. faecium and $100 \%$ susceptibility among $E$. faecalis). In contrast, high level resistance to gentamicin was observed in both species with $100 \%$ of resistance.

Chloramphenicol showed moderate activity against $E$. faecium, with $64.7 \%$ of susceptibility, but poor activity against E. faecalis $(81.2 \%$ resistance) (Table 2).

Ampicillin was very active against $E$. faecalis with $100 \%$ susceptibility, but none of the $E$. faecium isolates were susceptible to ampicillin.

The molecular pattern of the strains are shown on Table 1. Of the 16 Enterococcus faecalis submitted to molecular typing, 10 strains presented a unique molecular pattern, which was called I. The 6 remaining isolates also showed a unique molecular pattern distinct from pattern I and was called II. Twelve of the 17 Enterococcus faecium (71\%) strains showed a unique major pattern which was called A. This pattern presented 4 subtypes $\mathrm{A} 1, \mathrm{~A} 2, \mathrm{~A} 3$ and $\mathrm{A} 4$. The 5 remaining strains had distinct PFGE patterns, which were called D, G, $\mathrm{H}, \mathrm{E}$, and L. 


\section{Discussion}

Linezolid was the most active compound against our collection of multiresistant enterococci. It was the only antimicrobial agent active against all isolates at the susceptible breakpoint (100\% susceptibility) (Table 1). These data are in agreement with other published studies which show that the oxazolidinones represent a unique class of synthetic antimicrobials that maintain in vitro activity against multiresistant Gram-positive cocci, including vancomycin-resistant enterococci [15]. In addition to its excellent in vitro activity, in vivo studies with mice have shown results comparable to that of vancomycin for experimental systemic and soft tissue infections due to Enterococcus sp. [13]. Resistance and cross resistance with antimicrobial inhibitors of protein synthesis, such as chloramphenicol, macrolides, lincosamides, streptogramins, aminoglycosides, and tetracyclines, have not been demonstrated [4,21].

As expected, the streptogramin combination quinupristin/dalfopristin showed poor activity against $E$. faecalis [3]. However, the compromised activity of this compound ( $88.2 \%$ resistance) against $E$. faecium must be emphasized and has also been reported in Western Europe [22]. Resistance to quinupristin/dalfopristin has been associated with the presence of sat $\mathrm{A}$ and $s a t \mathrm{G}$ genes, which encode acetyltransferases that hydrolyze streptogramin A. Both genes are related to the acetyltransferase genes $v a t, v a t \mathrm{~B}$, and $v a t \mathrm{C}$ reported in staphylococci [10]. Resistance to streptogramin B has been related to the presence of $v g b, m s r \mathrm{~A}$, and $\operatorname{crm} \mathrm{B}$ genes. All three genes have been reported among staphylococci isolates, but only the erm $\mathrm{B}$ gene has been described among enterococci. The erm $\mathrm{B}$ gene is widespread among enterococci isolates and confers cross-resistance with macrolides and lincosamines due to modification in the ribosomal target [10].

Since most antimicrobial agents exhibit poor in vitro activity against enterococci, the options for the treatment of severe infections is generally restricted either to a glycopeptide or a $\beta$-lactam associated to an aminoglycoside. In our study, as shown in Table 1 , among the aminoglycosides that can be used to treat systemic enterococcal infections, only streptomycin showed adequate in vitro activity against the vancomycin resistant strains. High level resistance to streptomycin was not detected among the isolates evaluated. However, all isolates showed high level resistance to gentamicin.

Until recently, the epidemiology of enterococcal infections was poorly understood due to a lack of discriminatory typing methods. However, the application of molecular methods to clusters of glycopeptide-resistant enterococci has provided a greater insight into this problem, and, recently, PFGE has been shown to be useful for epidemiological evaluations of nosocomial enterococcal infections [5,23]. Although there have been a number of sporadic cases of infection caused by glycopeptide-resistant enterococci, most reports have described clusters of cases involving either a single or multiple strains of E. faecalis or, in particular, E. faecium [5].

The spread of a single strain of VRE has been reported from a number of other centers and the majority of these clusters have been confined to a single hospital unit. However, interhospital spread of VRE has also been reported, and it was, in some instances, attributable to the transfer of patients [5,24].

The finding of several strains with identical or similar PFGE patterns in different medical centers in our study strongly suggests interhospital spread of vancomycin resistant E. faecium and E. faecalis. Further studies are needed to investigate the mode of dissemination of these multiresistant strains.

Until recently, the treatment options for patients infected with VRE were extremely limited [4,25]. Only small and/or uncontrolled clinical trials and anecdotal case reports evaluated therapeutic options for VRE infections, including doxycycline, rifampicin, or chloramphenicol, alone and in various combinations [3, 25].

In addition to the excellent in vitro activity against VRE isolates shown in the present study and in several other investigations, intravenous and oral linezolid has produced high rates of clinical sucess in clinical trials involving hospitalized patients with skin or soft tissue pneumonia [15]. Thus, this study presents in vitro 
information that will be very helpful to determine the role of linezolid in the treatment of infections caused by multiresistant enterococci in Brazil.

\section{Acknowledegments}

The authors express their sincere thanks to Gilberto Turcato (Oswaldo Cruz Hospital), Thais Guimarães and Renato Grimbaum (Hospital do Servidor Publico Estadual), Reinaldo Salomão and Maria C. Lourenco (Hospital Santa Marcelina), Licia Mimica (Santa Casa de Misericordia de Sao Paulo) and to Libera M. Dalla Costa (Hospital de Clínicas do Paraná), who kindly sent us VRE isolates for this study. We also thank Ronald Jones and Ana Gales who provided us with the microdilution trays, and Rodrigo Mendes for technical support.

\section{References}

1. Loeb M., Salama S., Armstrong-Evans M., et al. A casecontrol study to detect modifiable risk factors for colonization with vancomycin resistant enterococci. Infect Control Hosp Epidemiol 1999;20:760-3.

2. Jochimsen E.M., Fish L., Manning K., et al. Control of vancomycin-resistant enterococci at a community hospital: efficacy of patient and staff cohorting. Infect Control Hosp Epidemiol 1999;20:106-9.

3. Ican Prevent Diseases and Organisms. Vancomycinresistant Enterococci (VRE) Treatment - EUA, Jun. 2000 [On line] http:// www.icanprevent.com. [July, 13 ${ }^{\text {rd }}, 2000$ last time accessed by the authors].

4. Chien J.W., Kucia M.L., Salata R.A. Use of Linezolid, an oxazolidinone, in the treatment of multidrug-resistant Gram-positive bacterial infections. Clin Infect Dis 2000;30:146-51.

5. Woodford N., Johnson A.P., Morrison D., Speller D. Current perspectives on glycopeptide resistance. Clin Microbiol Rev 1995;8:585-615.

6. Baptista M., Depardieu F., Courvalin P., Arthrur M. Specificity of induction of glycopeptide resistance genes in Enterococcus faecalis. Antimicrob Agents Chemother 1996;40:2291-5.

7. Dalla-Costa L. M., Souza D. C., Martins L. T .F., et al. Vancomycin-resistant Enterococcus faecium: first case in Brasil. Braz J Infect Dis 1998;2:160-3.
8. Sader H.S., Jones R.N., Ballow C.H., et al. Antimicrobial susceptibility of quinupristin/dalfopristin tested against Gram-positive cocci from Latin America: Results from the Global SMART (GSMART) Surveillance Study. Braz J Infect Dis 2001;5:21-30.

9. Johnson A. P., Warner M., Hallas G., Livermore D.M. Susceptibility to quinupristin/dalfopristin and other antibiotics of vancomycin-resistant enterococci from the UK, 1997 to mid-1999. J Antimicrob Chemother 2000; 46 : $125-8$

10. Bozdogan B., Leclerq R. Effects of genes encoding resistance to streptogramin $\mathrm{A}$ and $\mathrm{B}$ on the activity of quinupristin-dalfopristin against Enterococcus faecium. Antimicrob Agents Chemother 1999;43:2720-5.

11. Livermore D.M. Quinupristin/dalfopristin and linezolid: where, when, which and whether to use? J Antimicrob Chemother 2000;46:347-50.

12. Warner A.P., Livermore D.M. Activity of linezolid against multi-resistant Gram-positive bacteria from diverse hospitals in the United Kingdom. J Antimicrob Chemother 2000;45:225-30.

13. Schulin T., Thauvin-Eliopoulos C., Moellering R.C., Eliopoulos G.M. Activities of the oxazolidinones linezolid and eperezolid in experimental intra-abdominal abscess due to Enterococcus faecalis or vancomycinresistant Enterococcus faecium. Antimicrob Agents Chemother 1999;43:2873-6.

14. Noskin G.A., Siddiqui F., Stosor V., et al. In vitro activities of linezolid against important Gram-positive bacterial pathogens including vancomycin-resistant enterococci. Antimicrob Agents Chemother 1999;43:2059-62.

15. Clemett D., Markham A. Linezolid. Drugs 2000;59:815-27.

16. Facklam R., Sahm D. A., Teixeira L. M. Enterococcus. In: Murray, P.R., Baron, E. J., Pfaller, M. A., et al. (ed.). Manual of Clinical Microbiology. $7^{\text {th }}$ ed. American Society for Microbiology. Washington, DC, USA. 1999; p.297-305.

17. National Committee for Clinical Laboratory Standards (NCCLS) - Methods for dilution antimicrobial susceptibility tests for bacteria that grow aerobically, 5th - Approved standard M7-A5. Wayne, Villanova, PA, 2000.

18. National Committee for Clinical Laboratory Standards (NCCLS) - Performance standards for antimicrobial susceptibility testing; 10th informational supplement. M100-S10. Wayne, Villanova, PA, 2000.

19. Hamel J.C., Stapert D., Moerman J.K., Ford C.W. Linezolid, critical characteristics. Infection 2000;28:60-4.

20. Pfaller M. A., Jones R. N., Sader H. S. Chromosomal restriction fragments analysis by pulsed-field gel electrophoresis. In: Isenberg, H. D. - Clinical Microbiology Procedures Handbook., ASM Press Washington DC. USA. 1992; p.10.5.c.1-10.5.c.11. 
21. Fines M., Leclerq R. Activity of linezolid against Grampositive cocci possessing genes conferring resistance to protein synthesis inhibitors. J Antimicrob Chemother 2000; $45: 797-802$.

22. Soltani M., Beighton D., Philpott-Howard J., Woodford N. Mechanisms of resistance to quinupristin-dalfopristin among isolates of Enterococcus faecium from animals, raw meat, and hospital patients in Western Europe. Antimicrob Agents Chemother 2000;44:433-6.

23. Savor C., Pfaller M.A., Kruszynsky J.A., et al. Comparison of genomic methods for differentiating strains of Enterococcus faecium: Assessment using clinical epidemiologic data. J Clin Microbiol 1998;36:3327-31.

24. Boyce J.M., Opal S. M., Chow J.M., et al. Outbreak of multi-drug resistant Enterococcus faecium with transferable vanB class vancomycin resistance. J Clin Microbiol 1994;32:1148-53.

25. Murray B.E. Treatment options for infections caused by vancomycin resistant Enterococci - EUA, Jun.2000 [On line] http:// www.uptodate.com. [July, $14^{\text {th }}, 2000$, last time accessed by the authors]. 